\title{
Synthesis of Substituted Quinazolines Containing Pharmacophoric Groups
}

\author{
Harutyunyan Artur $\mathrm{A}^{1,2 *}$, Ghukasyan Gohar $\mathrm{T}^{1}$ and Danagulyan Gevorg $\mathrm{G}^{1,2}$ \\ ${ }^{1}$ Russian Armenian (Slavonic) University, Armenia, Europa \\ ${ }^{2}$ Scientific and technological center of organic and pharmaceutical chemistry, Armenia
}

Submission: September 28, 2018 Published: October 01, 2018

*Corresponding author: Harutyunyan Artur A, Scientific and technological center of organic and pharmaceutical chemistry National Academy of

Sciences of the Republic of Armenia, Armenia, Email: harutyunyan.arthur@yahoo.com

\section{Short Communication}

Continuing research on the synthesis of biologically active quinazoline derivatives [1,2] in this report we have described the synthesis of previously unknown substituted 2-methylquinzolins and 2-[2-aryl(hetaryl)vinyl]quinazolines, which contain pharmacophore groups at different positions of the ring. Synthesis was carried out by the interaction of 2-methyl-4H-3,1-benzoxzin4-ones $1 \mathrm{a}, \mathrm{b}$ with aromatic and heterocyclic amines, according to the Scheme 1.

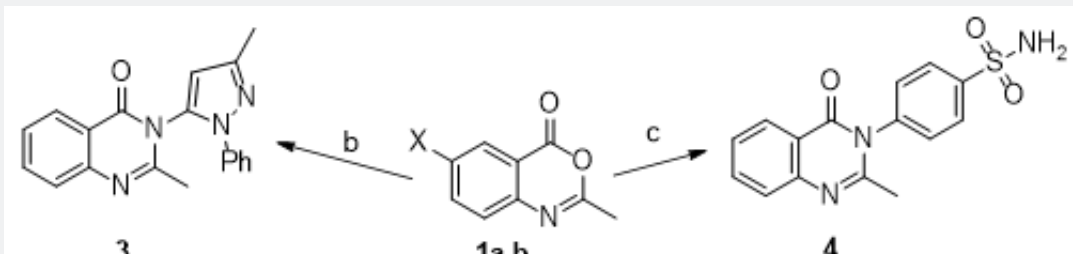

3 1a,b<smiles>CNc1ccc(-n2c(C)nc3ccccc3c2=O)cc1</smiles>

2<smiles>C[13CH3]</smiles><smiles>[R]c1nc2ccc(I)cc2c(=O)n1-c1ccc(Cl)cc1</smiles><smiles>COc1ccc(/C=C/c2nc3ccc(I)cc3c(=O)n2-c2ccc(Cl)cc2)o1</smiles>

6

Scheme 1.

1a, $\mathbf{b}: X=H(\mathbf{a}), I(\mathbf{b}) . a)$ 4-N,N-dimethylaminoaniline, b) 5-amino3-methyl-1-phenyl-1H-pyrazole, c) 4-aminobenzenesulfonamide, d) 4-chloroaniline, e) 5-nitrofuran-2-carbaldehyde.

Fragments of biologically active compounds are introduced into the target compounds:

4-N,N-dimethylaminoaniline, 3-methyl-1-phenylpyrazole, as well as fragments of antibacterial preparations of 4-aminobenzenesulfonamide and 5-nitrofuran. In the preparation of quinazolines $\mathbf{2 - 5}$, the best results are obtained when the reaction is carried out under the conditions of co-heating of benzoxazines $\mathbf{1 a}$, b with the corresponding amines, and quinazoline 3 in polyphos- phoric acid. Heating of 2-methylquinazoline $\mathbf{5}$ with 5-nitrofurancarbaldehyde in acetic anhydride gave the substituted (5-nitrofuryl)ethenylquinazoline 6 .

\section{References}

1. Harutyunyan AA, Ghukasyan GT, Panosyan HA, Danagulyan GG (2018) Chem J Armenia 71(1-2): 249-253.

2. Harutyunyan AA, Ghukasyan GT, Danagulyan GG (2018) International Conference 100 Years of Development of Chemistry: From Synthesis of Polyethylene to Stereodivergence. Dedicated to the $100^{\text {th }}$ anniversary of the Department of Organic Chemistry of Perm State University. Perm pp. 103. 
(CC) Commons Attribution 4.0 License BY DOI: 10.19080/OMCIJ.2018.08.555729
Your next submission with Juniper Publishers will reach you the below assets

- Quality Editorial service

- Swift Peer Review

- Reprints availability

- E-prints Service

- Manuscript Podcast for convenient understanding

- Global attainment for your research

- Manuscript accessibility in different formats ( Pdf, E-pub, Full Text, Audio)

- Unceasing customer service

Track the below URL for one-step submission https://juniperpublishers.com/online-submission.php 